\title{
Peculliarities of Usage of Phraseological Units in German Newspaper Text: Gender Aspect
}

\section{Iryna ZADOROZHNA' (D), Ivanna KOLOMYISKA² (1)}

${ }^{1}$ Assos. Prof., Yuriy Fedkovych Chernivtsi National University, Department of Germanic, General and Comparative Linguistics, Chernivtsi, Ukraine ${ }^{2}$ Assist. Prof., Yuriy Fedkovych Chernivtsi National University, Department of Germanic, General and Comparative Linguistics, Chernivtsi, Ukraine

ORCID: I.Z. 0000-0002-4317-7928 I.K. 0000-0002-0751-670X

\section{Corresponding author:} Ivanna Kolomyiska,

Yuriy Fedkovych Chernivtsi National University, Department of Germanic, General and Comparative Linguistics, Sadova Street 5a, Chernivtsi, Ukraine E-mail: ivannakol20@gmail.com

Submitted: 01.06 .2021

Revision Requested: 25.09.2021

Last Revision Received: 29.09.2021 Accepted: 29.09.2021

Citation: Zadorozhna, I., \& Kolomyiska, I. (2021). Peculiarities of usage of phraseological units in German newspape text: Gender aspect. Alman Dili ve Edebiyati Dergisi - Studien zur deutschen Sprache und Literatur, 46, 49-72

https://doi.org/10.26650/sds|2021-946348

\section{ABSTRACT (ENGLISH)}

The article is devoted to a comprehensive study of peculiarities of usage of phraseological units in German newspaper text depending on gender factor. Special attention has been paid to the analysis of quantitative characteristics. The influence of the gender factor on the processes of modification of phraseological units has been observed. With the help of linguistic statistic methods (criterion $\chi^{2}$ and Chuprov's contingency coefficient K) statistically significant quantitative differences in the usage of phraseological units by both sexes have been determined. The results of investigation conducted on the material of the Internetversions of two most popular German newspapers Die Zeit and Süddeutsche Zeitung have revealed quantitative differences in the usage of phraseological units by the two sexes mainly in "one-gender" speech. In "two-gender" speech the tendency to relative equality of communicators of both sexes has been observed. Among the phraseological units used in newspaper articles there is a group of units which is characterised by extremely high frequency of usage (hyper frequent) and which comprises "absolutely masculine", "absolutely feminine", "relatively masculine", "relatively feminine" and "gender indifferent" phraseological units. The processes of expansion and substitution have proved to be the most noticeable changes in the structure of both male and female phraseological usages. Significance of usage of elliptical phraseological constructions in "one-gender women" articles has also been statistically proved. Differences that exist in "one gender" newspaper article show that communication, namely its speech expression, depends upon the gender identity of both communicants.

Keywords: Phraseological unit, frequency of usage, gender, German newspaper text, modification 


\section{Introduction}

Present-day linguistic studies are focused on investigating linguistic phenomena through the prism of the human factor displayed in language. A special place among the scientific studies conducted in the line of anthropocentrism belongs to the research on the gender factor and its influence on the communication process. In particular, the gender identity of the speaker is studied on the phonetical (Zadorizhna, 2009), lexical (Holmes, 2003), syntactic (Kramer, 2016) levels and in different types of discourse, such as political (Holmes, 2003), family (Tannen, 2007), literary (Holmes, 2003), journalistic (Martyniuk, 2006), advertising (Bureichak, 2008) etc.

Specifically, linguistic gender studies address the following two issues:

1) language and the reflection of gender in it (studies are primarily concerned with the nominative system, lexicon, syntax, gender category, etc., as well as with the evaluation and characteristics attributed to men and women including semantic areas they are most noticeably / clearly expressed);

2) speech approach and communicative behaviour of members of different sexes in general (scholars distinguish typical speech strategies and tactics, gender-specific choice of language units, and ways to succeed in communication, etc., i.e. they study the specifics of male and female speech). Gender studies also deal with phraseology, where much attention is paid to the analysis of gender-marked phraseological units (PUN) that characterize the qualities, patterns of behaviour of the opposite sex, the relationship between them, etc. (Kapak, 2015; Kartushina, 2003; Kyrylina, 2005, etc.). Despite the significant number of gender studies in the fields of domestic and foreign linguistics and phraseology, in particular, the issues of identifying the gender characteristics of communicants in different types of speech remain unresolved.

The relevance of the chosen topic stems from the deep interest in gender studies, in particular, the ways language units of different levels function in texts representing different styles. Gender factor is also a necessary criterion to be emphasized given a need for a comprehensive analysis of the usage of phraseological units in modern newspaper text. 
The research aims to identify the peculiarities of the usage of phraseological units by men and women in a modern German-language newspaper text.

Achieving this goal involves completing further tasks:

- to determine the theoretical and methodological principles of studying the gender factor through the usage of phraseological units in the modern Germanlanguage newspaper text;

- to study the frequency of phraseological units used by men and women in newspaper articles and to identify the most frequent ones;

- identify "male" and "female" phraseological modifications in newspaper articles.

The object of study is represented by the German phraseological units recorded in modern German-language newspaper texts. The subject of the study is viewed in the peculiarities of their usage by men and women.

\section{Material and methods}

The data was retrieved from the daily leading German newspapers (Die Zeit, Süddeutsche Zeitung) published in 2013-2015 with a total number 1,697,040 of word usage. To verify the sufficiency of the research material for analysis and to formulate conclusions, we determined the value of the so-called sampling error exploiting statistical methods (Perebyinis, 2001):

$$
\delta=\frac{Z p}{\sqrt{N p}}
$$

Zp is a constant of 1.96 for a $5 \%$ significance level;

$\mathbf{N}$ is a sample size in absolute terms (number of word usages);

$\mathbf{p}$ is the relative frequency of word usage.

The error should not exceed 33\%.

In our study,

$\delta=\frac{1,96}{\sqrt{1697040 \times(13409 \div 1697040)}}=0,017$,

which validates a sufficient amount of sample material to make objective conclusions. 
The daily newspaper is the ideal outlet for a discourse analysis that opens up a wide range of opportunities for studying various linguistic phenomena. They do not only reflect the current state of language in general but also affect the structure of the language system. The analysed articles in Die Zeit and Süddeutsche Zeitung contain headings representing a wide range of different spheres of life. Both newspapers are the most popular in Germany. They play an important role in the German information space and have a significant influence on the formation of public opinion. Both newspapers have electronic versions.

Owing to the presence of different types of gender-specific articles in both newspapers, we consider it appropriate to divide the research material into the "one-" and "two-gender" text, taking into account the relationship "author - author", "author communicant". In particular, "one-gender" texts include articles written by either men or women, as well as those where the communicants are representatives of only one gender. "Two-gender" texts are represented in articles where either both men and women are the authors (e.g., comments and expressing the views of the editorial team on a particular event), or communication occurs between representatives of the opposite gender (this is predominantly an interview).

Quantitative methods were applied to serve several purposes: to study the frequency of phraseological units in a newspaper text, to compare the average frequency of phraseological units in "one-" and "two-gender" speech, to carry out the further division of phraseological units into low-frequency, medium-frequency and high-frequency, to examine the phraseological richness of gender-specific speech. The application of the structural method allowed researchers to investigate the use of different types of phraseological units modified depending on the gender factor.

The criterion $\chi^{2}$ (the chi-square criterion) is a fairly common method of testing statistical assumptions. It helps to identify similarities or differences between the frequency distributions of the studied phenomena. The higher the sum of $\chi^{2}$ is, the more empirical values deviate from theoretical ones. To interpret the results, it is necessary to assess the significance of the obtained sum $\chi^{2}$. To calculate $\chi^{2}$, they use the formula for four-part tables that consist of two rows and two columns. However, such tables can also be arranged into multi-fields, joining rows and columns. The sum of $\chi^{2}$ for such tables is calculated by the formula: 


$$
\chi^{2}=\frac{(a d \cdot b c)^{2} N}{(a+c)(b+d)(a+b)(c+d)},
$$

$\mathbf{a}, \mathbf{b}, \mathbf{c}, \mathbf{d}$ are empirical data in a four-field table,

$\mathbf{N}$ is the total sample size (Levickij, 1989).

Since the result of the chi-square criterion allows identifying either the presence or absence of a relationship between the usage peculiarities to determine its degree, it is reasonable to set the contingency coefficient $K$ (Levickij, 1989). It demonstrates not only the degree of the relationship but also the direction of its conjugation.

The significance might be established by the value of $\chi^{2}$. To calculate the value of the coefficient $\mathrm{K}$ the following formula is applied:

$$
\mathrm{K}=\sqrt{\frac{\chi^{2}}{N \sqrt{(r \cdot 1)(c \cdot 1)}}},
$$

$\chi^{2}$ is the chi-square criterion,

$\mathbf{N}$ is the sample size,

$\mathbf{r}$ is the number of horizontal rows in the table,

$\mathbf{c}$ is the number of vertical columns in the table.

In our study, a computer programme was used to calculate the statistical data regarding the value of $\chi^{2}$ and coefficient K. Application of statistical methods (criterion $\chi^{2}$ and contingency coefficient $\mathrm{K}$ ) enabled us to confirm the statistical significance of quantitative differences in the gender-affected usage of phraseological units in newspaper texts and to identify their inherent modifications.

\section{Discussion}

Phraseological units preserve information about myths, rites, customs, traditions, rituals, habits, morals, behaviour, as well as stereotypes and socio-historical factors of different groups of people (Wierzbicka, 2007, p. 24; Moiseienko, 2012, p. 521). According to Telia, the phraseological structure of language is a "mirror through which the linguistic and cultural community identifies its national identity (Telija, 1987, p. 82). Phraseological units "reflect mainly the everyday empirical, historical and cultural experience of the particular linguistic community associated with its cultural traditions" (Telija, 1987, p. 13) which qualitatively distinguishes them from the vocabulary as a generally viewed term. 
The reflection of such experience is carried out through the imagery that underlies the internal form of phraseological units (Moiseienko, 2012, p. 521). Theoretical research in phraseology covers a wide range of debatable issues in modern linguistics, among which the existence of a phraseological level in the language system and even the definition of the terms "phraseology" and "phraseological unit" are still controversial.

In modern linguistics, there are many terms, such as phraseological unit, phraseology, phraseme, idiom, phraseological inversion, stable phrase, collocation that mostly denote the same concept. The scholars usually define the notions of "phraseological unit" and "phraseologism" as identical, with a slight difference that mainly depends on the classification of phraseological units. In our study, we use the terms "phraseologism" and "phraseological unit" as synonymous, defining them as the "lexical and grammatical unit consisting of two or more different components, grammatically organized by the model of a phrase or sentence, which, having a holistic meaning, are reproduced in the language conventionally".

The central notions of gender linguistics remain debatable. Gender issues have interested mankind since ancient times and have always been examined through the prism of philosophy. However, when studying gender one should consider the linguistic perspective, as it is through language that the individual represents his own identity in society. Philosophical views on the role of men and women in society in different historical epochs became the impetus for the emergence and study of the gender lingualization of the world. The idea of gender differentiation and gender roles has become historically established in gender studies. The image of women as subservient to men, weaker and "secondary" has become conventional. However, already in the 1970s. gender linguistics (or linguistic gender studies) started to develop rapidly, due to shifts in both political and scientific paradigms. Moreover, the rise of gender studies corresponded to a widely-held anthropocentric approach to the study of linguistic phenomena. If earlier there was a tendency to use the terms "gender" and "sex" as synonymous, today most scholars distinguish them by defining sex as drawing on biological characteristics of the individual. Conversely, gender, as a term introduced by feminist scientists, is defined through socio-cultural characteristics.

The notion of gender asymmetry as the opposition of the masculine to the feminine is pivotal in gender linguistics. This asymmetry is justified by biological nature, which translates into social, dealing with speech behaviour and differences in cognitive 
processes. The dichotomy of gender linguistics is manifested in various types of discourse, which are intensively studied by both foreign and domestic linguists (Kapak, 2015; Kyrylina, 2005; Holmes, 2003; Kotthoff, Nübling, 2018; Tannen, 2007).

Gender stereotypes and norms "impose" and "attribute" various characteristics and features of communicative behaviour to the representatives of both sexes. Stereotypically, in speech men dominate, and women take a subordinate position. However, contemporary studies demonstrate the opposite view and show that women's speech is not so much a "deviation" from the norm. It has its characteristics, which distinguishes it from the "male" and should be treated with equal respect. Women's speech should not be seen as a violation of rules and regulations just because it is simply somewhat different from the language of the opposite sex.

Socio-historical, social, cultural, and ethnic factors contributed to the existing differences between "male" and "female" speech. Such differences are inextricably linked to the lifestyle of women and existing stereotypes and norms in society, which is reflected in the language. In modern linguistics, we trace the shifts caused by the feminist language movement, which either portray a woman as more "visible" in speech or gender-neutralize it promoting language tolerance. Thus, the objective of this study is to identify possible gender asymmetry at the phraseological level.

\section{Results}

\subsection{Quantitative characteristics}

To verify the validity of the suggested methodology, we researched the basis of newspaper articles. After having analysed 581 "one-gender" articles (amounting to 662340-word usages (hereinafter WU)) found in the weekly newspaper Die Zeit issued during 2013-2015, we managed to collect 1680 PUN (4396 phraseological usages (hereinafter PUS)): 1225 PUN (3546 PUS) in 441 "male" articles (502740 WU), and 455 PUN (850 PUS) - in 140 "female" articles (159600 WU).

After having analysed 764 "one-gender" articles (550,080 WU) in the daily newspaper Süddeutsche Zeitung we found 1447 PUN (3904 PUS): 991 PUN (2997 PUS) in 575 "male" articles (414000 WU), where the authors and communicants are men, and 456 PUN (907 PUS) - in 189 "female" articles (136080 WU) (see Table 1). 


\begin{tabular}{|c|c|c|c|c|c|c|c|c|}
\hline \multirow{2}{*}{ Table 1: Quantitative characteristics of the usage of phraseological units in "one-gender" newspaper articles } \\
\cline { 2 - 9 } & $\begin{array}{c}\text { The } \\
\text { number } \\
\text { of } \\
\text { articles }\end{array}$ & $\begin{array}{c}\text { The } \\
\text { number } \\
\text { of WU }\end{array}$ & $\begin{array}{c}\text { The } \\
\text { number } \\
\text { of PUN }\end{array}$ & $\begin{array}{c}\text { The } \\
\text { number } \\
\text { of PUS }\end{array}$ & $\begin{array}{c}\text { The } \\
\text { number } \\
\text { of } \\
\text { articles }\end{array}$ & $\begin{array}{c}\text { The } \\
\text { number } \\
\text { of WU }\end{array}$ & $\begin{array}{c}\text { The } \\
\text { number } \\
\text { of PUN }\end{array}$ & $\begin{array}{c}\text { The } \\
\text { number } \\
\text { of PUS }\end{array}$ \\
\hline Die Zeit & 441 & 502740 & 1225 & 3546 & 140 & 159600 & 455 & 850 \\
\hline Süddeutsche Zeitung & 575 & 414000 & 991 & 2997 & 189 & 136080 & 456 & 907 \\
\hline \multicolumn{1}{|c|}{ Total } & 1016 & 916740 & 2216 & 6543 & 329 & 295680 & 911 & 1757 \\
\hline
\end{tabular}

Thus, in general, the average frequency of phraseological units used by men in "onegender" articles in Die Zeit is approximately 1 PUS per 142 WU (502740 WU per 3546 PUS), by women - 1 PUS per 188 WU (159600 WU per 850 PUS), which is significantly lower than in men's speech. The average frequency phraseological units used by men in "onegender" communication in Süddeutsche Zeitung is approximately 1 PUS per 138 WU (414000 WU per 2997 PUS), women - 1 PUS per 150 WU (136080 WU per 907 PUS), which is also significantly lower than in men's speech.

Table 2 presents the peculiarities of the usage of phraseological units by both men and women in "two-gender" newspaper articles (see Table 2).

\begin{tabular}{|c|c|c|c|c|c|c|c|c|}
\hline \multicolumn{1}{|c|}{ Table 2: Quantitative characteristics of the usage of phraseological units in "two-gender" newspaper articles } \\
\hline The newspaper & \multicolumn{3}{|c|}{ Men } & \multicolumn{5}{|c|}{ Women } \\
\hline & $\begin{array}{c}\text { The } \\
\text { number } \\
\text { of } \\
\text { articles }\end{array}$ & $\begin{array}{c}\text { The } \\
\text { number } \\
\text { of WU }\end{array}$ & $\begin{array}{c}\text { The } \\
\text { number } \\
\text { of PUN }\end{array}$ & $\begin{array}{c}\text { The } \\
\text { number } \\
\text { of PUS }\end{array}$ & $\begin{array}{c}\text { The } \\
\text { number } \\
\text { of } \\
\text { articles }\end{array}$ & $\begin{array}{c}\text { The } \\
\text { number } \\
\text { of WU }\end{array}$ & $\begin{array}{c}\text { The } \\
\text { number } \\
\text { of PUN }\end{array}$ & $\begin{array}{c}\text { The } \\
\text { number } \\
\text { of PUS }\end{array}$ \\
\hline Die Zeit & 163 & 185820 & 559 & 1162 & 163 & 185820 & 622 & 1382 \\
\hline Süddeutsche Zeitung & 415 & 298800 & 554 & 1136 & 415 & 298800 & 631 & 1429 \\
\hline Total & 578 & 484620 & 1113 & 2298 & 578 & 484620 & 1253 & 2811 \\
\hline
\end{tabular}

As shown in Table 2, 163 "two-gender" articles (amounting to 185,820 WU) of the weekly newspaper Die Zeit contain 559 PUN (1162 PUS) used by men and 622 PUN (1382 PUS) used by women. Thus, in general, the average frequency of phraseological units used by men in "one-gender" articles in Die Zeit is approximately 1 PUS per 160 WU (185820 WU per 1162 PUS), by women - 1 PUS per 134 WU (185820 WU per 1382 PUS), which indicates, on the contrary, more frequent use of phraseological units used by women in communication with men. 415 "two-gender" articles (298800 WU) in 
Süddeutsche Zeitung contained 1185 PUN (2565 PUS): 554 PUN (1136 PUS) used by men and 631 PUN (1429 PUS) used by women. The average frequency of phraseological units used by men in "two-gender" articles in Süddeutsche Zeitung is approximately 1 PUS per 263 WU (298800 WU per 1136 PUS), women - 1 PUS per 209 WU (298800 WU per 1429 PUS), which indicates more frequent use of phraseological units by women in conversation with men.

The data obtained from the analysis of both newspapers and Tables 1. and 2. illustrates that the average frequency of use of phraseological units used by men in "one-gender" communication is approximately 1 PUS per 140 WU (916740 WU per 6543 PUS), by women - 1 PUS per 168 WU (295680 WU per 1757 PUS), which is slightly lower than in men's speech. In "two-gender" communication, men use 1 PUS for 211 WU (484620 WU per 2298 PUS), and women use 1 PUS for 172 WU (484620 WU for 2811 PUS), which indicates a trend opposite to the quantitative characteristics of "one-gender" communication, meaning that if in one-gender articles the quantitative advantage in usage of phraseological units belongs to men, in "two-gender" speech, on the contrary, women use phraseological units more often, which means that females in communication with the opposite sex do not want to concede in language, including their phraseological competence, and try to convey the necessary information more accurately and with greater emotional emphasis.

To confirm or refute the significant difference between the frequency of usage of phraseological units by men and women, we used the criterion $x^{2}$ and the contingency coefficient $\mathrm{K}$. The results are shown in Table 3 (see Table 3).

\begin{tabular}{|l|c|}
\hline \multicolumn{2}{|l|}{ Table 3: Statistical characteristics of phraseological units used by men and women in newspaper texts } \\
\hline M (OG) & $\chi^{2}=18,82, \mathrm{~K}=0,05$ \\
\hline W (OG) & - \\
\hline M (TG) & - \\
\hline W (TG) & - \\
\hline
\end{tabular}

The calculations yielded the following results: in "one-gender" male communication, the value of $\chi^{2}$ is equal to 18.82 , and $\mathrm{K}=0.05$; no significant statistical indicators were found in "two-gender" communication. Drawing on the fact that the value of $\chi^{2}$ in the "one-gender" men's speech was more than 3.84 (this is the initial rate for calculating statistical characteristics), and $\mathrm{K}$ was more than 0 , we make a statistically confirmed 
conclusion that in "one-gender" speech men use phraseological units more often than women, and in "two-gender" speech there is no significant difference between the usage of phraseological units by men and women.

The tendency to more frequent usage of phraseological units by men in "one-gender" newspaper articles may indicate a desire for dominance over the communicant (man). Conversely, the lack of discrepancies between the frequency of phraseological usages in "two-gender" articles may serve as evidence that women, as mentioned above, are trying to match men in their phraseological competence, while men, on the other hand, are probably willing to talk with women on equal terms and to be more comprehensible in speech.

Indicators of phraseological diversity (phraseological richness) of masculine and feminine speech show how many times each phraseological unit is used by either man or woman. The smaller the share of the division of the total number of PUN per each PUS, the higher the degree of diversity of the phraseological units. Consequently, the more phraseological abundant the speech of men and women is. In the "one-gender" speech in Die Zeit, men use the same PUN about three times (3546 PUS per 1225 PUN), and women use it about twice (850 PUS per 455 PUN). The articles in Süddeutsche Zeitung represent communicants who are exclusively men or women. Men use the same phraseological units about three times (2997 PUS per 991 PUN), women - about twice (907 PUS per 456 PUN). Such a tendency indicates a greater diversity of phraseological units used in female "one-gender" communication, and on the other hand, highlights general tendencies of German newspaper speech regarding the usage of phraseological units by both men and women.

The analysis of "two-gender" articles found in both newspapers demonstrates that both men and women use the same PUN about twice (Die Zeit: 1162 PUS per 559 PUN; 1382 PUS per 622 PUN; Süddeutsche Zeitung: 1136 PUS per 554 PUN; 1429 PUS per 631 PUN). The obtained statistical data indicates that there are no quantitative differences in usage of PUN by men and women in "two-gender" communication.

Interestingly, if we had conducted a study without dividing into the "one-" and "twogender" communication, the result of a general analysis regarding the frequency of usage of the same phraseological units would still have shown a tendency for women to use phraseological units more diversely (see column "Total" in Table 1: men: 8841 PUS per 3329 $\mathrm{PUN} \approx 3$, and women: 4568 PUS per $2164 \mathrm{PUN} \approx 2$ ). Thus, in "one-gender" communication 
phraseological diversity is greater in feminine speech; in "two-gender" communication there are no distinct differences. We assume that in communication with women men strive for greater phraseological diversity of their speech.

The analysis of the newspaper articles under study concluded that there is a different frequency of phraseological units used both by men and women. As found above, the average frequency of usage of the same phraseological unit by men is three times, and by women is twice. Thus, phraseological units with a frequency lower than the average belong to low-frequency, with medium - to medium-frequency, and with a frequency higher than the average - to high-frequency units. The results of the quantitative analysis are shown in Tables 4 and 5 (see Tables 4 and 5).

Table 4: Gender-specific peculiarities of the usage of different-frequency phraseological units

\begin{tabular}{|c|c|c|c|c|c|c|}
\hline The newspaper & \multicolumn{2}{|c|}{ Die Zeit } & \multicolumn{2}{|c|}{ Süddeutsche Zeitung } & \multicolumn{2}{|c|}{ Total } \\
\hline Communicant & $\mathrm{m}$ & w & $\mathrm{m}$ & w & $\mathrm{m}$ & w \\
\hline Type of communication & \multicolumn{6}{|c|}{ "One-gender" } \\
\hline Low-frequency PUN & $930(76 \%)$ & $327(72 \%)$ & $738(74 \%)$ & $297(65 \%)$ & $1668(75 \%)$ & $624(68 \%)$ \\
\hline Medium-frequency PUN & $106(9 \%)$ & $63(14 \%)$ & $76(8 \%)$ & $89(20 \%)$ & $182(8 \%)$ & $152(17 \%)$ \\
\hline High-frequency PUN & $189(15 \%)$ & 65 (14\%) & $177(18 \%)$ & $70(15 \%)$ & $366(17 \%)$ & $135(15 \%)$ \\
\hline Total & 1225 & 455 & 991 & 456 & 2216 & 911 \\
\hline Type of communication & \multicolumn{6}{|c|}{ "Two-gender" } \\
\hline Low-frequency PUN & $383(69 \%)$ & $411(66 \%)$ & $351(63 \%)$ & $398(63 \%)$ & $734(66 \%)$ & $809(64 \%)$ \\
\hline Medium-frequency PUN & $91(16 \%)$ & $103(17 \%)$ & $99(18 \%)$ & $120(19 \%)$ & 190 (17\%) & $223(18 \%)$ \\
\hline High-frequency PUN & $85(15 \%)$ & $108(17 \%)$ & $104(19 \%)$ & $113(18 \%)$ & $189(17 \%)$ & $221(18 \%)$ \\
\hline Total & 559 & 622 & 554 & 631 & 1113 & 1253 \\
\hline
\end{tabular}

As shown in Table 4, the differences in the usage of different-frequency phraseological units by men and women are illustrated primarily in "one-gender" speech. For instance, in Die Zeit men are slightly more likely than women to use low-frequency PUN (the frequency is less than three times per article), and medium-frequency PUN, on the other hand, are less commonly used by men than women. As for the high-frequency PUN, they are used in communication almost equally by both men and women.

The male "one-gender" newspaper articles in Süddeutsche Zeitung contain a greater number of low-frequency PUN, and women are also more likely than men to use mediumfrequency PUN. High-frequency PUN are more common in men's speech. 
The analysis of the contexts containing discursive realizations of PUN enabled us to conclude that there are no particular differences in the usage of multi-frequency PUN in the "two-gender" articles in both newspapers. The examples of contextual actualisation of PUN in men's and women's speech are provided below.

Low-frequency PUN. Die Zeit 三 men's speech: "Fleisch niemand essen mag, haben die Bauern kein Interesse an ihrer Aufzucht" - [Nobody likes to eat meat, the farmers have no interest in raising it]; women's speech: ... bloß wird sich die Begeisterung dafür bei den Schülern in Grenzen halten - [only the enthusiasm will be limited among the students]. Süddeutsche Zeitung $\equiv$ men's speech: "Aber kann man für Speisen überhaupt das Urheberrecht in Anspruch nehmen?" - [But can you even take advantage of the copyright for food?]; women's speech: Sollte solcher Personenkult nun Schule machen, ahnen wir, was noch kommt... - [If such a personality cult should now set a precedent, we can guess what is to come ...].

Medium-frequency PUN. Die Zeit = men's speech: “Das Geld soll vor allem den Städten Slowjansk und Kramatorsk zugute kommen, die von der Armee im Kampf gegen Separatisten kürzlich zurückerobert wurden" - [The money is intended primarily to benefit the cities of Slovyansk and Kramatorsk, which were recently recaptured by the army in the fight against separatists]; women's speech: "In zweiter Linie geht es irgendwie auch um bürgerliche Grundrechte, wie sie seit der Französischen Revolution vom aufgeklärten Teil der Menschheit beansprucht warden" - [Secondly, it is also about basic civil rights, as they have been claimed by the enlightened part of humanity since the French Revolution]. Süddeutsche Zeitung $\equiv$ men's speech: "Aber wie kurz der Weg dahin ist, mit der gleichen Logik auch Journalisten unter Druck zu setzen, sieht man jetzt" - [But you can now see how easy it is to put journalists under pressure]; women's speech: "So lange sie noch zu keinem Ergebnis gekommen seien, wolle sie nicht über mögliche Kosten spekulieren" - [As long as they have not yet come to a conclusion, they do not want to speculate about possible costs].

High-frequency PUN. Die Zeit झ men's speech: "Im Gegenteil, behauptet eine Studie: Fast alles, was die Nachwende-Generation über die DDR weiß, hat sie von Eltern und Großeltern gelernt" - [On the contrary, one study claims that almost everything the post-reunification generation knows about the GDR they learned from their parents and grandparents]; women's speech: "In der Euro-Krise etwa konnte man den Eindruck gewinnen, nur die anderen Staaten hätten ein Problem und Deutschland stünde gut da" - [In the euro crisis, 
for example, one could get the impression that only the other countries had a problem and that Germany was doing well]. Süddeutsche Zeitung $\equiv$ men's speech:"Jeder bei uns hat heute eine wichtige Rolle gespielt" - [Every one of us played an important role today]; women's speech:"Jedenfalls sagt man dem Kellner nie direkt, wie viel Tip man ihm gibt, sondern lässt entweder eine höhere Kreditkartenrechnung oder ein paar Scheine auf dem Tisch zurück" - [In any case, you never tell the waiter directly how much tip you are giving him, but either leave a higher credit card bill or a few bills on the table].

To verify the statistical significance of the identified differences, we use the criterion $x^{2}$ and contingency coefficient $\mathrm{K}$. The results are shown in Table 5 (see Table 5).

\begin{tabular}{l}
\hline $\begin{array}{l}\text { Table 5: Statistical characteristics of the usage of different frequency PUN in various types of gender } \\
\text { communication }\end{array}$ \\
\hline
\end{tabular}

Thus, we managed to statistically prove (see Table 5) the tendency of men to use lowfrequency PUN in "one-gender" articles, which indicates their desire to sound more "sophisticated" in the usage of PUN, while women reveal the tendency to use mediumfrequency PUN. Regarding "two-gender" communication, both men and women use mostly medium-frequency PUN.

Thus, the main difference in the usage of multi-frequency PUN by both sexes is manifested mainly in "one-gender" communication, where men tend to use low-frequency PUN more often, and women more often than men use medium-frequency PUN, which corresponds to the average frequencies of usage. No significant differences were found in "one-gender" speech, which proves the assumption of gender equality of communicants in "one-gender" interaction and "blurred" gender boundaries in the usage of PUN.

Besides, among the high-frequency PUN, we distinguish hyper-frequency ones that are found in men's / women's speech extremely often. To determine the so-called 
"reference point" of the hyper-frequency of the used PUN in the text, we divide the sum of the usages of high-frequency PUN by their number. We get the following indicators:

1) Die Zeit:

a) "one-gender" speech: men - 2139 PUS: 189 PUN = 11 (meaning that all PUN, used by men in Die Zeit, more than 11 times belong to hyper-frequent ones); women - 393 PUS: 65 PUN = 6;

6) "two-gender" speech: men - 606 PUS: 85 PUN = 7; women - 763 PUS: 108 PUN = 7, meaning that the usage of PUN is the same for both sexes;

2) Süddeutsche Zeitung:

a) "one-gender" speech: men - 1850 PUS: 177 PUN = 10; women - 432 PUS: 70 PUN = 6;

6) "two-gender" speech: men - 588 PUS: 104 PUN = 6; women - 793 PUS: 113 PUN = 7 , meaning that there is a slight difference in the communication of both sexes.

Therefore, it is noticeable that in both newspapers, identification indicators of hyperfrequency are similar, which may reflect a general trend in the quantitative usage of individual PUN in German-language newspaper texts.

The most used among the hyper-frequency PUN in the speech of both men and women, and both in the "one-" and "two-gender" articles found in Die Zeit and Süddeutsche Zeitung were the following PUN: vor allem - [especially] (778 PUS), es geht um etw. - [it's about sth.] (approximately 500 PUS), am Ende - [in the end] (355 PUS), immer wieder - [again and again] (234 PUS), zur Zeit - [at the moment] (151 PUS), zu tun haben mit etw. - [to do with sth.] (135 PUS), etw. liegt an etw. - [sth. is due to sth.] (112 PUS), eine Rolle spielen - [play a role] (110 PUS), es geht j-m - [it is about] (106 PUS), zur Verfügung stehen - [are available] (101 PUS), unter anderem - [among others] (100 PUS), nicht einmal - [not even] (91 PUS).

The predominance of the aforementioned PUN in the communication of both men and women can also be explained by the specifics and topicality of the studied newspaper articles that reflect mainly public life and the person within it. However, we trace different frequency of individual hyper-frequency PUN in men's and women's speech, distinguishing between "relatively masculine" (those that are present in the speech of both genders, but predominate in "male" communication), "relatively feminine" (those that are present in the speech of both genders but predominate in "female" 
communication), "absolutely masculine" (used only by men), "absolutely feminine" (used exclusively by women) and "gender indifferent" (used by communicants of both sexes with approximately the same frequency) hyper-frequency PUN. Since the "male" articles are three times more numerous than the "female" ones, we consider "relatively masculine" those PUN that are 4 times more numerous than the "female" ones.

We managed to collect the following data: "one-gender" articles: 11 "relatively masculine" PUN (e.g., vor allem - [especially], immer wieder - [again and again]);"relatively feminine" PUN (e.g., es geht j-m gut / schlecht - [it goes well / badly], einen Eindruck Machen - [make an impression]); "two-gender" articles: 1 "relatively masculine" PUN (etw. ernst nehmen (meinen) - [to take sth. seriously]), 1 "relatively feminine" PUN (nicht einmal - [not even]); 27 "absolutely masculine" PUN (e.g., Einfluss haben - [have influence], in der Tat - [as a matter of fact], unter Druck setzen - [put under pressure]); 7 "absolutely feminine" (e.g., im Einsatz sein - [be in use], auf den ersten Blick - [at first glance], Wer die Wahl hat, hat die Qual - [If you have a choice, you are spoiled for choice]). "One-gender" articles: 3 "gender indifferent" PUN (e.g., auf jeden Fall - [definitely], eine Rolle spielen [play a role]); "two-gender" articles: 15 "gender indifferent" PUN (e.g., unter anderem [amongst other things], zur Zeit - [for now]).

The results of the study demonstrate the following: "one-gender" articles: the biggest number of "relatively masculine" PUN (11), less number of "gender indifferent" PUN (3) and "relatively feminine" PUN (3); "two-gender" articles: the biggest number of "gender indifferent" PUN (15); 1 "relatively masculine" PUN and 1 "relatively feminine" PUN, which is quite logical, given the gender of communicants.

Thus, the results of the study allow us to claim the prevalence of "absolutely masculine" PUN over "absolutely feminine" ones (27 vs. 7), "gender indifferent" (18) and "relatively masculine" PUN over "relatively feminine" ones (12 vs. 4). That is, there are phraseological units that are preferred by either men or women and in "two-gender" communication women match men in their phraseological competence (12 "gender indifferent" PUN in "two-gender" articles in comparison to 6 PUN in "one-gender" articles).

\subsection{Modifications}

The phraseological unit is one of the most vivid and most effective language tools. Metaphorical nature, emotionality, expressiveness, which are inherent in these stable 
compounds, provide language and speech with imagery and expressiveness. Those units reflect not only people's perception of the world and its specific mental features but also language itself in all its complexity and versatility. It is this complexity that is the reason for intensive research and the constant interest of linguists in the field of phraseology, who note a noticeable tendency to change and modify the component composition of stable compounds. Many Ukrainian and foreign scientists have studied the modification of phraseological units in the German language (Ptashnyk, 2003, p. 198; Burger, 2007, p. 265; Fleischer, 1997, p. 274; Palm, 1995, p. 283). Fedorenko states that there is a need to further develop and refine the classification system of modification types of phraseological units (Fedorenko, 2007), as their composition is being constantly replenished through such powerful sources as advertising, press, TV where phraseological units and their modifications are extremely common.

Modifications of stable phrases are quite motivating, as they help to achieve additional expression, more precisely to activate the phraseological unit, as well as to adapt it to new socio-political processes, events, phenomena, facts, and realities. Phraseological modifications attract the attention of readers, bring the text closer to the audience at any level, deepening the content and complementing it with additional shades of meaning either humorous or satirical. Ptashnyk argued that phraseological modifications are an important means of pragmatic influence on the recipient, which is the main purpose of the media. Depending on the presence or absence of transformations two types of phraseological units can be distinguished: (a) structural modifications (these include substitution, expansion, reduction, coordination, contamination, grammatical modifications, changes in the external potential of actants); (b) contextual (these include actualization of the phraseological meaning of phraseological units in combination with the direct meaning; dominant actualization of the direct meaning of phraseological units in comparison to figurative one; simultaneous realization of direct and phraseological meanings). Mixed forms of modifications are widely used in the press (Ptashnyk, 2003).

In our study, we focus on quantitative indicators of structural and semantic types of modifications, because they predominate over contextual ones. Structural-semantic modifications of phraseological units are characterised by the change in their meaning (semantics). These modifications include expansion, substitution, phraseological ellipse, contamination and double actualization. For instance, expansion is one of the most common types of phraseological units, which is characterized by the expansion of the component composition by adding additional lexemes. 
Expansion, as a rule, expands, supplements and specifies the meaning of phraseological units.

Substitution is the replacement of one or more components of phraseological units by other lexemes.

Phraseological ellipse is a reduction of the component composition through omitting one or more of its components of phraseological units, with their meaning being kept quite clear.

Contamination is a type of modification that involves a blending of two or more phraseological units within one. In this case, some of the components are reduced, although only the core part of basic phraseological units participates in contamination (Wotjak, 1992).

Double actualization presupposes contextual usage of phraseological units with their meaning either acquiring new shades or demonstrating the semantic duality of its components (Davydenko, 2012). In this way, both the direct and phraseological meaning of a stable combination is expressed. This type of modification is also relatively rare. In our study, cases of double actualization were not detected at all.

Having studied the processes of modification in "one-gender" speech in newspaper articles in Die Zeit, we found 2420 examples (almost 55\% of the total number of PUS), and in Süddeutsche Zeitung - 2948 cases (76\%) of modified phraseological units. The results of the analysis are shown in Table 6 (see Table 6).

\begin{tabular}{|c|l|c|c|c|c|c|c|}
\hline \multicolumn{2}{|c|}{ Table 6: "Male" and "female" phraseological modifications in "one-gender" articles } \\
\hline \multirow{2}{*}{ № } & Modification Type & \multicolumn{2}{|c|}{ Die Zeit } & Süddeutsche Zeitung & \multicolumn{2}{c|}{ Total } \\
\cline { 3 - 8 } & & M & W & M & W & M & W \\
\hline 1. & Expansion & $835(44 \%)$ & $201(38 \%)$ & $1062(49 \%)$ & $370(48 \%)$ & $1897(47 \%)$ & $571(44 \%)$ \\
\hline 2. & Substitution & $818(43 \%)$ & $256(48 \%)$ & $852(39 \%)$ & $289(37 \%)$ & $1670(41 \%)$ & $545(42 \%)$ \\
\hline 3. & Ellipse & $226(12 \%)$ & $68(13 \%)$ & $234(11 \%)$ & $107(14 \%)$ & $460(11 \%)$ & $175(13 \%)$ \\
\hline 4. & Contamination & $14(1 \%)$ & $2(1 \%)$ & $27(1 \%)$ & $7(1 \%)$ & $41(1 \%)$ & $9(1 \%)$ \\
\hline \multicolumn{2}{|l}{ Total } & 1893 & 527 & 2175 & 773 & 4068 & 1300 \\
\hline
\end{tabular}


Thus, as Table 6 shows, the most noticeable changes in the structure of both masculine and feminine PUN are the processes of expansion (Wie sonst nur in Baden und Berlin gewinnen die Demokraten hier echten Einfluss? - [How else do the Democrats gain real influence in Baden and Berlin?]; In Italien wiederum übersteigt die Staatsschuld die Wirtschaftsleistung um ein Vielfaches. Ihr Abbau ist überfällig, aber nicht in erster Linie zur Erfüllung des Stabi-Pakts, sondern vor allem im Interesse aller jungen Italiener - [In Italy, on the other hand, the national debt exceeds economic output many times over. Its dismantling is overdue, but not primarily to fulfil the Stabi Pact, but above all acts in the interests of all young Italians]; Münchner Philharmoniker hat Wellhöfer einen guten Draht zu den Musikern und konnte dieses Konzert ermöglichen - [Munich Philharmonic Wellhöfer has a good connection to the musicians and was able to make this concert possible]) and substitution (... denn nur so lässt sich das riesige Verwaltungsproblem in den Griff kriegen (instead of bekommen - [to get]) - [...because this is the only way to get the huge administrative problem under control]; Künftig will der Verein verstärkt an die Öffentlichkeit gehen, das sei in jüngster Zeit vernachlässigt (instead of kommen - [to come] - [In the future, the association wants to go public more intensely, which has recently been neglected]); Der Betrieb solcher Internetseiten soll nun in Frankreich unter Strafe stehen (instead of stellen - [to put]) - [The operation of such websites is now said to be a criminal offense in France]). In addition, the expansion appears to be more represented in PUN used by men (on average in $46 \%$ of cases, while in women's speech $43 \%$ ). On the contrary, substitution prevails in women's speech (on average in $43 \%$ of cases; while in men's speech - 41\%).

One of the most significant differences in the process of modification is that substitution prevails in the "women's" articles Die Zeit, in contrast to other articles where preference is given to expansion). Ellipse and contamination are equally presented in both men's and women's speech, and appear to be not very popular in speech (Es kann gut sein, dass die ersten Krisenländer es aus eigener Kraft auf die Füße schaffen und damit zeigen, dass sich Opfer lohnen - [lt may well be that the first crisis countries get to their feet on their own and thus show that sacrifices are worthwhile]; Die 75-jährige Heilwig Weger, die im Rahmen der Ausstellung “Der Lebensborn” im Ludwig-Thoma-Haus ein Zeitzeugengespräch führte, steht jedoch für die Kinder jener Zeit, die ihr Leben lang Schuld auf ihren Schultern tragen - einfach, weil sie zur falschen Zeit am falschen Ort auf die Welt kamen - [The 75-year-old Heilwig Weger, who held a contemporary witness interview as part of the exhibition "Der Lebensborn" in the Ludwig-Thoma-Haus, stands for the children of that time, who have carried guilt on their shoulders all their lives - 
simply because they were born in the wrong place and at the wrong time]).

The most significant difference in the process of modification was its quantitative characteristics, depending on both the newspaper and the gender factor. Thus, the analysis revealed that "one-gender" newspaper articles in Süddeutsche Zeitung contain more cases of modified PUN (on average $80 \%$ of contextual usage) than in Die Zeit (59\%). Moreover, women are more likely to modify PUN (74\% on average) than men (64\% on average), which may indicate greater flexibility and creativity in their speech in comparison to men's speech.

The analysis of "two-gender" articles in Die Zeit collected 1591 cases of modified PUN (approximately $63 \%$ of the total number of PUS). In Süddeutsche Zeitung - 2127 PUN (83\% of PUS). Besides, in "two-gender" texts, "male" and "female" no gender-specific peculiarities of the usage of PUN were found. The results of the quantitative analysis of modifications are shown in Table 7 (see Table 7).

Table 7: "Male" and "female" modifications of PUN in the "two-gender" articles

\begin{tabular}{|c|l|c|c|c|c|c|c|}
\hline \multirow{2}{*}{ № } & \multirow{2}{*}{ Modification Type } & \multicolumn{2}{|c|}{ Die Zeit } & \multicolumn{2}{c|}{ Süddeutsche Zeitung } & \multicolumn{2}{c|}{ Total } \\
\cline { 3 - 8 } & & M & W & M & W & M & W \\
\hline 1. & Expansion & $294(41 \%)$ & $381(43 \%)$ & $511(54 \%)$ & $626(53 \%)$ & $805(48 \%)$ & $1007(49 \%)$ \\
\hline 2. & Substitution & $325(45 \%)$ & $407(47 \%)$ & $339(36 \%)$ & $416(35 \%)$ & $664(40 \%)$ & $823(40 \%)$ \\
\hline 3. & Ellipse & $92(13 \%)$ & $77(9 \%)$ & $83(9 \%)$ & $126(11 \%)$ & $175(11 \%)$ & $203(10 \%)$ \\
\hline 4. & Contamination & $6(1 \%)$ & $9(1 \%)$ & $9(1 \%)$ & $17(1 \%)$ & $15(1 \%)$ & $26(1 \%)$ \\
\hline \multicolumn{2}{|l}{ Total } & 717 & 874 & 942 & 1185 & 1659 & 2059 \\
\hline
\end{tabular}

Table 7 shows that the number of modified PUN used in "two-gender" speech does not differ significantly (except for the more frequent usage of ellipses in men's speech in Die Zeit). The main difference in usage of modified PUN in communication between men and women is that in the Die Zeit articles they prefer substitution as modification type of PUN (e.g., Diese Kurse sollen irgendwie zum Ziel haben, die Menschen, die hierher kommen (instead of setzen - [put]) - [These courses are meant to target the people who come here]), and in the Süddeutsche Zeitung articles they prefer expansion (e.g., Das große Interesse zeige die hohe Motivation der Flüchtlinge, Deutsch zu lernen und sich integrieren zu wollen. Keiner will Zaungast sein oder sich im Nichtstun ergehen - [The great interest shows high motivation of the refugees to learn German and to want to integrate. Nobody wants to be an onlooker or indulge in idleness]). It should be noted that the most frequent parts of speech used by men and women in both types of 
communication in case of expansion were adjectives and adverbs, in substitution - verbs, in an ellipse - mostly articles, in contamination - a combination of mostly 2 PUN.

Another significant difference between men and women in the usage of modified PUN in communication (both in "one-gender" and "two-gender" articles) is that in Süddeutsche Zeitung modified PUN occur much more often than in Die Zeit. Also, in the "one-gender" articles, women tend to use modified PUN more often than men. The results of statistical analysis of quantitative data are demonstrated in Table 8 (see Table 8).

Table 8: The frequency of modification types in newspaper texts

\begin{tabular}{|c|c|c|c|c|}
\hline & Expansion & Substitution & Ellipse & Contamination \\
\hline $\mathrm{M}(\mathrm{OG})$ & - & $\chi^{2}=0,29$ & $\chi^{2}=0,19$ & - \\
\hline $\mathrm{W}(\mathrm{OG})$ & - & $\chi^{2}=0,87$ & $\chi^{2}=8,19, \mathrm{~K}=0,03$ & - \\
\hline $\mathrm{M}(\mathrm{TG})$ & $\chi^{2}=1,64$ & - & - & \\
\hline $\mathrm{W}(\mathrm{TG})$ & $\chi^{2}=3,47$ & - & - & $\chi^{2}=1,83$ \\
\hline
\end{tabular}

As shown in Table 8, the ellipse was statistically the most significant modification type in female "one-gender" communication. This may be connected with the belief that women understand women better, and therefore save the words in their communication. Besides, the usage of elliptical structures testifies to the significant emotionality of communicants, which encourages the reader's reflection. Espersen demonstrated that elliptical constructions are more common in women's speech, in particular, at the syntactic level (Espersen, 2006).

At the same time, there are cases of using several modification techniques within one phraseological unit. The most common is a combination of expansion and substitution (e.g., das andere Geschlecht bleiben - [to remain the opposite sex] (das starke Geschlecht - [masculinity]), sein zweifelsfrei hässlichsten Gesicht zeigen - [to show one's ugliest face], (sein wahres Gesicht zeigen - [to show one's true face]), etw. griffbereit zur Hand haben - [to have something at one's fingertips] (etw. zur Hand nehmen - [at one's fingertips])). It is also important to note that some phraseological units were modified and became widely used, but the old form remained in the dictionary (e.g., auf Grund [based on] according to modern rules is written together and is a preposition requiring a genitive case; the dictionary form of auf die Dauer - [permanently] is very rare, mostly used as elliptical form without the article - auf Dauer - [permanently]), which indicates the need for systematic review and updating of lexicographic sources. 


\section{Conclusion}

The overall measurement results of the study led to the conclusion that in "onegender" articles in the newspapers Die Zeit and Süddeutsche Zeitung there is a tendency to more frequent use of phraseological units by men, and in "two-gender" articles there are no quantitative differences between men's and women's usage of phraseological units. Phraseological units are more diverse in the "one-gender" women's speech. However, no particular differences were found in "two-gender" articles.

Men and women use in their speech phraseological units with different frequency characteristics. In "one-gender" communication, men tend to use low-frequency phraseological units, and women - medium-frequency ones. No significant differences were found in "two-gender" speech.

Among hyper-frequency phraseological units, we distinguish "absolutely masculine", "absolutely feminine", "relatively masculine", "relatively feminine" and "gender indifferent" ones. In "two-gender" speech, "gender-indifferent" phraseological units appeared the most frequently, which confirms the tendency to equality and testifies to the absence of significant differences in communication between men and women. Many examples of "absolutely masculine" and "absolutely feminine" phraseological units were found obvious.

The most noticeable changes in the transformation of the structure of both "masculine" and "feminine" phraseological units were expansion and substitution. In "women's" newspaper articles in Die Zeit, the substitution predominates. In contrast, expansion dominates in "men's" speech recorded in newspaper texts. The articles in Süddeutsche Zeitung are characterized by a higher degree of usage of modified phraseological units than the articles in Die Zeit. Besides, in "one-gender" speech, women transform phraseological units more often than men, which indicates greater flexibility and creativity in their speech. In "two-gender" speech, the modification of phraseological units used by men and women do not differ significantly. Statistical data obtained during the study indicates the prevalence of ellipsis as the modification type of phraseological units in female "one-gender" communication.

The study has shown that in "two-gender" communication there are no significant differences between the peculiarities of the usage of phraseological units by men and women. In "one-gender" speech the language design of media communication depends 
on the gender of both communicants. Men use more phraseological units in communication with each other, obviously trying to prove their dominance. Women use fewer phraseological units than men, but more diversely, using many elliptical constructions, meaning that they are more emotional, flexible and creative, and less willing to show intellectual dominance. Thus, in their communication with men, women are equal communicants matching men in their phraseological competence.

Ethics Committee Approval: Ethics committee aproval is not required for this study.

Peer-review: Externally peer-reviewed.

Author Contributions: Conception/Design of Study- I.Z., I.K.; Data Acquisition- I.Z.; Data Analysis/InterpretationI.Z., I.K.; Drafting Manuscript- I.K.; Critical Revision of Manuscript I.Z.; Final Approval and Accountability- I.Z., I.K.

Conflict of Interest: The authors have no conflict of interest to declare.

Grant Support: The authors declared that this study has received no financial support.

\section{List of abbreviations}

PUS - phraseological usage

PUN - phraseological unit

OG - one-gender

TG - two-gender

\section{References}

Amosova, N. N. (2010). Osnovy anglijskoj frazeologii. Moskva: Librokom.

Bureichak, T. S. (2008). Reklamni stratehii konstruiuvannia normatyvnykh gendernykh dyskursiv (na prykladi suchasnoi ukrainskoi telereklamy). Visnyk Lvivskoho universytetu. Seriia: sotsiolohichna. Lviv: Vydavnytstvo Lvivskoho natsionalnoho universytetu. Vypusk 2. s. 227-242.

Burger, H. (2007). Phraseologie / Phraseology: Ein internationales Handbuch zeitgenössischer Forschung. Berlin; New York: An International Handbook of Contemporary Research Walter de Gruyter.

Davydenko, L. B. (2012). Avtorski modyfikatsii frazeolohichnykh odynyts u khudozhnomu movlenni. Naukovi zapysky Nizhynskoho derzhavnoho universytetu imeni Mykoly Hoholia. Seriia: Filolohichni nauky. s. 30-33.

Die Zeit. Available at: http://www.zeit.de.

Duden. Deutsches Universalwörterbuch. (2006). Hrsg. von G. Drosdowski. Mannheim; Wien; Züric: Dudenverlag.

Duden. Redewendungen und sprichwörtliche Redensarten: Wörterbuch der deutschen Idiomatik (1997). Bearbeitet von Günther Drosdowski und Werner Scholze-Stubenrecht. Nach den Regeln der neuen dt. Rechtschreibung überarb. Nachdr. der 1. Aufl. Mannheim; Leipzig; Wien; Zürich: Dudenverlag.

Espersen, O. (2006). Filosofija grammatiki. Moskva: KomKniga. 
Fedorenko, L. O. (2007). Modyfikatsii strukturnoho i semantychnoho skladu frazeolohizmiv suchasnoi nimetskoi movy. Zhytomyr: Visnyk Zhytomyrskoho derzhavnoho universytetu imeni I. Franka. Vyp. 34. S. 193-197.

Fleischer, W. (1997). Phraseologie der deutschen Gegenwartssprache. Tübingen: Max Niemeyer Verlag.

Holmes, J. (2003). The Handbook of Language and Gender. Oxford: Blackwell Publishing.

Kapak, Yu. M. (2015). Aktualizatsiia hendernoho komponenta semantyky frazeolohichnykh odynyts u nimetskomu publitsystychnomu teksti. Avtoreferat dysertatsii na zdobuttia naukovoho stupenia kandydata filolohichnykh nauk. Spetsialnist 10.02.04 - Hermanski movy. Lviv.

Kartushina, E. A. (2003). Gendernye aspekty frazeologii v massovoj kommunikacii. Dissertacija kandidata filologicheskih nauk. Special'nost' 10.02.19 - Teorija jazyka. Izhevsk.

Kazmierczak, A. (2007). Die Problematik der Phraseologismen in der deutschen Sprache. Ein Überblick. München: GRIN Verlag.

Kolomyiska, I. A. (2017). Osoblyvosti vzhyvannia phraseolohichnykh odynyts u nimetskomovnomu hazetnomu teksti: hendernyi aspekt. Dysertaziya kandydata philologichnyh nauk. Spezial'nist' 10.02 .04 - Germans'ki movy. Chernivtsi, Zaporizhzhia.

Kotthoff, H., Nübling, D. (2018). Genderlinguistik. Eine Einführung in Sprache, Gespräch und Geschlecht. Tübingen: Narr Francke Attempto.

Kramer, R. (2016). The Location of Gender Features in the Syntax. Wiley Online Library.

Kyrylina, A. V. (2005). Linhvistychni henderni doslidzhennia. Vitchyzniani zapysky. 2.

Levickij, V. V. (1989). Statisticheskoe izuchenie leksicheskoj semantiki. Kiev: UMKVO.

Martyniuk, A. P. (2006). Rehuliatyvna funktsiia hendernomarkovanykh odynyts movy (na materiali suchasnoho anhlomovnoho publitsystychnoho dyskursu). Avtoreferat dysertatsii na zdobuttia naukovoho stupenia doktora filolohichnykh nauk. Spetsialnist 10.02.04 - Hermanski movy. Kyiv. Kyivskyi natsionalnyi universytet imeni T. Shevchenka.

Moiseienko, L. (2012). Frazeolohichni odynytsi yak obiekt doslidzhennia: nimetski, polski ta ukrainski paraleli. Kyivski polonistychni studii: naukove vydannia. Kyivskyi natsionalnyi universytet imeni T. Shevchenka. Instytut literatury imeni T. H. Shevchenka NANU; Mizhnarodna shkola ukrainistyky. Kyiv. T. 19. s. 521-526.

Palm, Chr. (1995). Phraseologie. Eine Einführung. Tübingen: Gunter Narr Verlag.

Perebyinis, V. I. (2002). Statystychni metody dlia linhvistiv. Vinnytsia: Nova knyha.

Ptashnyk, S. B. (2003). Strukturno-semantychni osoblyvosti frazeolohichnykh modyfikatsii ta yikh funktsii u nimetskomu hazetnomu teksti. Avtoreferat dysertatsii na zdobuttia naukovoho stupenia kandydata filolohichnykh nauk. Spetsialnist 10.02.04 - Hermanski movy. Lviv.

Skrypnyk, L. H. (1973). Frazeolohiia ukrainskoi movy. Kyiv: Naukova dumka.

Smirnickij, A. I. (1998). Leksikologija anglijskogo jazyka. Moskva: Moskovskiy Gosudarstvennyy Universitet.

Süddeutsche Zeitung. Available at: http://www.sueddeutsche.de/archiv/muenchen.

Sulikowska, A. (2019). Kognitive Aspekte der Phraseologie. Konstituierung der Bedeutung von Phraseologismen aus der Perspektive der Kognitiven Linguistik. Berlin: Peter Lang.

Tannen, D. (2007). You Just Don't Understand: Women and Men in Conversation. New York: Morrow.

Telija, V. N. (1966). Chto takoe frazeologija. Moskva: Nauka. 
Telija, V. N. (1987). Frazeologizm i ego leksikograficheskaja razrabotka. Moskva: Nauka.

Wierzbicka, A. (2007). Słowa klucze: różne języki - różne kultury. Warszawa: Wydawnictwa UW.

Wotjak, B. (1992). Verbal Phraseolexeme in System and Text. Tübingen: Max Niemeyer Verlag.

Zadorizhna, N. I. (2009). Prosodychni markery hendernoi variatyvnosti movlennia (eksperymentalno-fonetychne doslidzhennia na materiali anhlomovnoho dyskursu radioreklamy). Avtoreferat dysertatsii na zdobuttia naukovoho stupenia kandydata filolohichnykh nauk. Spetsialnist 10.02.04 - Hermanski movy. Kyiv: Kyivskyi natsionalnyi universytet imeni Tarasa Shevchenka. 